long and colorful career of public service and private enter. prise was over. By the end of the war, Mayers had eight children: Floyd, Gilbert, Howard S., Jane B. ("Jennie"), J. T., H. P., Hattie, and Lina, the last named being born in $1862 .{ }^{60}$ With such a large family and postwar conditions as they were, it is unlikely that Mayers's last years were prosperous ones. He died at Fort Smith on February 16, $1870^{70}$

'M M653-R50: Crawford County 1390-1289; NAMP, M593 (Population Schedules of the United States, 1870)-R64: Crawford County 37-41. By 1889 only Howand Jennie (Mrs, T. J. Cunninghad living. See Goodspeed's History, 1345. 20Allsopp, History of the Arkansas Press, 416. Mrs. Mayers died August
27, 1885; see Goodspeed's History, 1345.

\section{A Black Protest in the \\ "Era of Accommodation:" Documents}

\author{
By J. MORGAN KOUSSER* \\ California Institute of Technology
}

$\mathbf{I}_{\mathrm{N}}$ IN HIS SEMINAL ESSAY ON THE DEVELOPMENT OF LEGAL segregation in the South, C. Vann Woodward listed several "restraining forces" which delayed the formalization of the strict caste system-"Northern liberal opinion . . . the prestige and influence of Southern conservatives ... [and] the idealism and zeal of the Southern radicals [i.e., Populists]." It was the "weakening and discrediting" of these groups which allowed Jim Crow to grow and prosper. Al. though the "Woodward thesis" has repeatedly been debated, historians have often overlooked a central fact: each of the restraining groups was white. In the controversy over the place of the Negro in southern society, in other words, black folk weren't directly involved. For, by the 1890s, according to Woodward, "The resistance of the Negro himself had long ceased to be an important deterrent to white aggression."1 Perhaps. But assuming the truth of the state-

- Several scholars and the staffs of numerous libraries have assisted me by attempting to track down information on the little-known sub. jects of this paper. I want especially to thank Professors Willard B. Gatewood, Jim Green, Melton A. McLawin, and William Warren Rogers, and the staffs of the following libraries: Arkansas History Commission, Boston Public Library, Chicago Historical Society, Chicago Public Library, Cook County Law Library, Library of Congress (Manuscript Division), Pine Bluff and Jefferson County Public Library, and the Law Depart. ment, City of Chicago.

Dr. Kousser is associate professor of history at California Institute of Technology at Pasadena.

${ }^{1} \mathrm{C}$. Vann Woodward, The Strange Career of Jim Crow, 2 nd rev. ed. 
ment, was the Negro no longer a restraining force because black resistance had died out, or because white aggression was overwhelming? Did the accommodationist public posture of Booker $\mathbf{T}$. Washington reflect the thoughts of all southenn Negroes, or did Callcasians simply ignore more militant black voices they had no wish to hear?

Historical evidence points increasingly to the latter answer to each of the rhetorical questions. Published accounts which detail black resistance to segregation before the establishment of the National Association for the Advancement of Colored People in 1909 include parts of works by Woodward, Otto Olsen, and August Meier and Elliott Rudwick. Negro state legislators as well as black civic leaders in Louisiana, Georgia, and, as the following documents will show, in Arkansas, strongly denounced proposed Jim Crow laws. ${ }^{2}$ Their speeches and actions demonstrate that the local black elite in the South, far from meekly capitulating to the racist assault, carried on the protest tradition of Frederick Douglass and the militant black reformers. Not included in books of primary source readings in Afro-American history, or in any other published works, the speeches and resolutions from Arkansas may more closely reflect the mood of the lower-echelon black leaders than the declamations and essays of such national figures as

${ }^{2}$ C. Vann Woodward, "The National Decision Against Equality," in American Counterpoint: Slavery and Racism in the North-South Dialogue (Boston, 1971). 212-233; Otto H. Olsen, Carpetbagger's Crusade: The Iife of Albion Winegar Tourgee (Baltimore, Maryland, 1965), 309-310, 326-331: Olsc1, The Thin Disguise: Turning Point in Negro History, Plcssy V. Ferguson, A Documentary Presentation, 1864-1896 (New York, 1967); August Meier and Elliott Rudwick, "The Boycott Movemen Against Jim Crow Strcetcars in the South, 1900-1906," Journal of American History, 55 (March 1969), 756-775. Negroes held a well-attended comvention in Nilanta in November 1892, to enter their protest against the Germgia Jim. Sec Knoxyille (Tem.) Daily Journal, Nov. 18, 1892, Alluntı (Gia.) Daily Constiturion, Nov. 18, 24, 1892. For more information on the response by hacks in Arkansas to the separate coach law of 1891 and for morc information about the Arkansas black leaders see Willard 3. Catewood, Jr., "Ncgro Legislators in Arkansas, 1891: A Document," Alkansas Historical Oumlerly, XXXI (Autumn 1972), 220-233; Gatewood, "Irkinsis Negrocs in the 1890s: Documents," ibid., XXXIII (Winter 197 1). 293-325; and John W. Graves, "The Arkansas Separate Coach Law of 1891," ibid., XXXII (Summer 1973), 148-165.
Booker T. Washington, T. Thomas liortune, or W. L. B. Dubois.

The very existence of the Arkansas documents deuronstrates the attention which even such a racist Democratic newspaper as the Little Rock Arkansas Gazettc accorded to black resistance to segregation in 1891. After all, belore the passage of the secret ballot and poll tax acts, Arkansas Negroes retained a good deal of political power. According to my estimates, 70 per cent of the Negro adult males in Arkansas voted in the 1890 gubernatorial election, the vast majority of them for the Republicans. Eleven of the ninetyfive state representatives in the 1891 legislative session were black-probably the second highest percentage of black representatives in any legislature in the country at that time. ${ }^{3}$ Although it denounced their position editorially, the Gazette gave front-page coverage to two Negro protest meetings and devoted three and one-half columns-more than to any other single speech during the legislative sessionto a verbatim report of the chief attack on the Jim Crow bill.

Not only do they show that the black man participated in the debate over Jim Crow, these speeches raise some unanswered, even unasked questions about the course of racism in the South: Were there geographical differences in race relations in the late nineteenth century? Other things being equal, did whites in the older, settled regions discriminate more or less than those in the newer states which had only recently emerged from frontier conditions? Before rigid segregation imposed a single caste pattern on the South, did blacks fare better where the paternalistic traditions of the eastern plantation still lingered, or did they receive more humane treatment in the less structured

The Iouisiana legislature of 1890 contained a larger number of blacks, sixteen. Sce John W. Graves, "The Arkansas Negro and Segrcgation, 1890-1903" (unpublished M.A. thesis, University of Arkansas, 1967) For a discussion of suffrage restriction in Arkansas and refcrences to secondary literature on the subject, sce J. M. Kousser, "The Shaping of Party South, 1890-1910 (unpublished Ph.D. dissertation, Yale University, $1971)$. 
societies where inherited mores did not so strictly constrain social relationships?

Arkansas Negroes claimed that race relations were better in their state during the 1880 s than anywhere else in the South. John Gray Lucas, a young graduate of Boston University Law School, and, by 1891, both state representative and commissioner of the United States Circuit Court at Pine Bluff, had told a northern newspaper reporter in 1886 that he "did not see why more colored young men from the North did not make Arkansas their home. It is an inviting field for them, and a grand opportunity to make something of themselves. A very liberal public sentiment exist[s], and no hindrances are met with anywhere." Remarking that "there was neither distinction nor separation [by race] made by public carriers" in Arkansas, Lucas also pointed out that in Pine Bluff, Negroes held three of the eight seats on the common council and the offices of county coroner and circuit court clerk. Half the police force and half of the justices of the peace were black, and Negroes often served on juries. ${ }^{4}$ And according to Rev. Asberry Whitman, blacks in Arkansas were "making more progress than in any other State. ..."

After 1890, however, race relations in Arkansas began to deteriorate. To defeat the second fusion campaign of the Agricultural Wheel (predecessor of the Farmers' Alliance) and the Republicans in 1890 , the Democrats seem to have increased their usual race-baiting. Employing racism to counter the economic appeals of the fusionists, who campaigned under the "Union Labor" party label; the Democrats pledged to enact a law requiring segregation in railroad cars. The actual bill was copied from the Mississippi statute, which the United States Supreme Court in 1890 had ruled a valid regulation of commerce. ${ }^{5}$

Reacting to the introduction of the separate car bill, Little Rock Negroes held two mass meetings-one in the state legislative chamber itself-and adopted a set of strong

'Roston (Mass.) Daily Globe. Dec. 6, 1886

${ }^{8}$ Louistillc N. O. \& T. R. Co. v. Mississippi, 133 U.S. 587 (1890). denunciatory resolutions. In addition, several of the black state legislators attacked the law. Denying the inherent inferiority of their race, the blacks did admit that whites currently held superior positions in the United States. But the glories of ancient Egypt and Ethiopia and the startling progress of the race in the South since emancipation proved the Negro capable of great things. Appealing to the egalitarian tradition enshrined in the Declaration of Independence, Senator George Waltham Bell and Representative Lucas chided the Democracy for deserting the ideals of their party's founder, Thomas Jefferson, and demanded that white America make good on its promises of equality. Theretofore, there had been little segregation in public accommodations or housing, the legislators claimed (a claim which tends to support Woodward's chief thesis in The Strange Career of Jim Crow). Whites did not mind having Negro nurses, servants, or barbers. And many blacks were cleaner, better educated, wealthier and more cultivated than some whites. ${ }^{b}$ Yet even these Negroes wanted only civil, not social equality. So why, the Afro-American solons asked, did whites suddenly demand railroad segregation?

Representatives R. C. Weddington and John Gray Lucas found the answer in the political enmity between the two major parties. Weddington charged that white Democrats wanted to segregate the darker race because the blacks refused to vote the Democratic ticket in Arkansas. And during a seconding speech for the Republican candidate for the United States Senate, Lucas arraigned the Democratic party for "its oppressive policy against the colored race." "He assumed a defiant attitude," the newspaper report went on, "giving the dominant party to understand that if it wanted any assistance from the colored people it would have to go and ask them for it." In striking contrast to the famous hand and fingers metaphor Booker T. Washington used in his 1895 Atlanta Exposition address, Iucas declared (in the reporter's summary) that:

-Information from Robert Baumruk to author, May 12, 1972; Larry A. Viskochil to author, May 20, 1972. 
"He went to the [Democratic] party, not with an olive branch in his hand, but with a bundle of arrows, showing that his race was united, and if political friendship between the whites and blacks was desirable, it remained with the whites to say so."7

There was a note of militancy, too, in the Negro leaders' prophecies that increasing segregation and discrimination would drive blacks to desert Arkansas for the West or even for Africa. Already, they said, labor and colonizationist agents were urging blacks to emigrate. And their statements showed that, perhaps chiefly because of frustration, separatist tendencies were gaining ground in the black community. When an amendment to the Jim Crow law providing for segregation on street cars was proposed, Lucas supported it, avowing that

he did not want to associate with white people any more than they desired to associate with him. He would like to see separate coaches placed on all railroads; separate cars or partitions on all street railway lines, and he would be in favor of having streets and sidewalks divided by some line so that the colored people could go on one side and the white people on the other.

He would like to see an end put to all intercourse be tween white and colored people by day, and especially by night. ...8

The men who declaimed these rather pretentious speeches were the leaders of their not very affluent, not very well educated, not very influential communities. While we cannot be sure, therefore, that their statements reveal the beliefs of the black masses, their lives were a good deal closer to the majority than those of the national Negro leadership of the day. Rising from typical poverty-stricken backgrounds, several of these men had had promising careers before 1891. They were not selected by the white community to serve as spokesmen for their race; the whites had no choice but to accept them as spokesmen. The pat-

TLittle Rock Arkansas Gazette, Jan. 21, 1891.

'Ibid., Feb. 14, 1891 . terns of their lives thus indicate a larger transition in south. ern society. From 1865 to about 1890, outstanding southern blacks could hope to gain an education and then thrust themselves into politics as independent, forthright representatives of their race's interests. After that point, until the fairly recent past, most blacks would have to cmigrate to the North, choose other professions, or settle for the role of white-appointed race leader, with all the constraints that role imposed on their statements and actions. ${ }^{\circ}$

If the sparse biographical information on the early years of five of the Arkansas black leaders testifies to the possibilities open to ambitious, talented Negro men in the pre-1890 South, the little we know of their post-1890 careers shows how closely their success was tied to that of the black community as a whole. Born in Marshall, Texas, in 1864, Representative John Gray Lucas grew up in Pine Bluff, Arkansas, and attended grammar schools and the Branch Normal school (now the University of Arkansas at Pine Bluff) there. The only Negro in his class of fifty-two at Boston (Mass.) University Law School, he graduated with high honors in 1887. Returning to Pine Bluff, he became, successively, assistant prosecuting attorney and United States Commissioner in the Eastern District of Arkansas, and served as well on the county, congressional district, and state Republican committees. In the eyes of the white Democratic press of Arkansas, he was "a fluent debater," "unquestionably the ablest and most brilliant representative of his race in the state, and it might be truthfully said (for his age) in the South," "a born leader of his people" for whom in 1891 "there is certainly a bright future in store. . . ."10

But by 1893 Lucas had joined the immigration to the North and had settled in Chicago. Here he became a "highly successful attorney," with "white as well as black clients." He was active in Republican politics and held several appointments. Later on he switched to the Demo.

But sce note 14, below.

${ }^{10}$ Gazette, Jan. 31, 1891; Little Rock Arkansas Democrat, Apr. 1, 1891. 
cratic party, and in 1934 was "named Assistant United States Attorney under the administration of Franklin D. Roosevelt."11

Senator George Waltham Bell was born in Tennessee in 1855, and, like Lucas, was brought up in Arkansas. Left fatherless at the end of the war, Bell supported his family and somehow made enough money to attend private schools and send himself through Lincoln University in Pennsylvania, where he graduated first in his 1883 class of twenty. A schoolteacher and Republican politician, he served as well as secretary of the state executive board and state organizer of the extremely active Arkansas Knights of Labor. He was apparently fairly wealthy, for he was said to have paid the tuition of 140 young men to college. As a Quaker, non-smoker, and teetotaler, Bell received the respect of his white senate colleagues more for his quiet demeanor than any fiery brilliance. Nevertheless, he was a firm and often clever defender of the interests of his race. Realizing that the legislature of 1891 would probably pass a bill to pension ex-Confederate soldiers, Bell proposed one providing subsidies for ex-slaves as well and defended it in a speech the Gazette felt good enough to merit full quotation.12

Bell was not the sole black Quaker in the legislature. Another Friend, J. N. Donohoo, had been born in eastern Tennessee in 1854. The only one of the major black leaders who had never attended college, Donohoo was a farmer and grocer who owned a good deal of land in Phillips County. By 1891, he was serving his tenth year in the legislature. Representative R. C. Weddington of Desha County was a graduate of Alcorn University in Mississippi and the principal in the black elementary school in Arkansas City. He had emigrated from his native Mississippi in $1887 . .^{13}$

The only native Arkansan of this group of five blacks was Joseph Albert Bookcr. I.ike the others born too late

${ }^{11}$ Gatewood, "Negro Legislators in Arkansas, 1891," 224.

1:Gazelle and Democrat, Mar. 26, 1891.

"Indianapolis (Ind.) Freeman, Apr. 4, 1891; Gatcwood, "Arkansas Negrocs in the 1890s," 302n.
(1859) to have been shaped by slavery, Booker attended Branch Normal College in Pinc Bluff and reccired both bachelor's and master's degrees from Roger Williams University in Nashville, Tennessee. Settling in Little Rock in 1889, he became editor of the bi-wcekly Baptist Vanguard. a Negro religious and political newspaper; he was also president of and professor at a small Negro college, Arkansas Baptist, in Little Rock. He continued to be active in educational and race affairs in Arkansas for the next four decades. ${ }^{14}$

Articulate, proud of their race, and conscious of its traditions and accomplishments, these militant leaders led the broad-based black protests against discrimination in public accommodations in Arkansas. That the Jim Crow law passed was not due to the passivity of the black community, but to the increasing racism of the white.

\section{DOCUMENT NO. 1 :}

\section{Resolution of Negro Mass Meeting}

Last night some 600 of the more respectable and orderly citizens of Little Rock assembled at the First Baptist Church (colored) and adopted a set of ringing resolutions remonstrating against the passage of any bill by the Legislature looking to the forcible separation of the races into different cars, while travelling on the railroads of Arkansas.

As usually customary with the colored people, the meeting was opened with prayer and closed with intense excitement.

1I. G. Penn, The Afro-American Press and Its Editors (Springfield Mass, 1891) 258-262. Who Was tWho in Anerica, vol. 1, 1897-1942 (Chicaso, 1942), 116. His son, Joseph Robert Booker carried on his father. cago, 1912), 116. His son, Joseph Robert Booker, carred on his father's activism, becoming one of the leading black cin rights lawyers in the south. Int . J . Booker ince an ame of the important post-World War II attacks on segregation in public facilitics the successful effort to overturn Jim Crow railroad dining cars on inter state trains in Henderson v. U.S., 339 U.S. 816. The example of the Book ers shows that civil rights activity, though muted, never fully died out in the South, and that the local black clites carried on a tradition of advocacy of equal rights (National Cyclopedia, 1968, pp. 154-155). 
The bill introduced in the Senate by Mr. Tillman, ${ }^{15}$ of Washington County, was read, and of course called forth voluminous comment. A committee was then appointed to draft resolutions expressing the sense of the meeting on the injustice of the bill, flanked by a monster petition from the colored women of the city who set up, in substance, that a quiet and respectable negro was not more objectionable than a drunken and boisterous white man to the traveling public.

The resolutions adopted were as follows:

We, the colored citizens of the city of Little Rock in mass meeting assembled, adopt the following resolutions:

Whereas, numerous bills have been introduced in the Arkansas Legislature, having for their avowed purpose and object the forcible separation and isolation of the "white and African races upon the passenger trains of the railways of this State," which bills in any form whatever, should any one of them become a law. would operate with great discrimination against and injustice to the colored citizens of this State; and,

Whereas, Such a law, whatever its provisions may be, will invite the special insult, contumely and imposition of a certain well known class of white persons; and,

Whereas, The colored people generally, and the colored ladies especially, must, if this law be passed, unavoidably encounter and unnecessarily be subjected to forcible usage, insult, injury and indignity, at the hands of the class of

\footnotetext{
15 John Newton Tillman was born December 13, 1859, in Springfield, Missouri, but moved with his parents as a young boy to Washington County, Arkansas. In 1880 he graduated from the University of Arkansas. While pursuing a teaching career, he studied law and was admitted to the Arkansas bar in 1889. He was elected circuit clerk of Washington County (1884-1888) and to one term (1889-1891) in the state senate, where he introduced the scparate coach bill. From 1892 to 1898 he served is prosccuting attorney of the Fourth Circuit and as juige of the same circuit from 1900 until he was elected president of the University of Arkansas in 1905. He scrved in this position until 1912. In 1915 he was clected is Congress and scrved until March 3, 1929. He died in Fayetteville on March 9, 1929. John Hugh Reynolds and David Yancey Thomas, viveory of the University of Arkansas (Fayetteville 1910) 135.436;

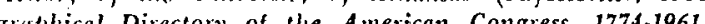
(United States Goscrument Printing office, 1961), 1717
}

public servants usually entrusted with the enforcement of these laws upon common carriers; therefore, be it

Resolved, That we sincerely and strongly condemn all bills introduced in the Legislature, which have for their object the forcible separation of its citizens upon the rail ways of this State upon the basis of color or race, as caste and class legislation, which has no place in our country, and should find no expression upon the statutes of this, our State, and be it

Resolved, That any law in contemplation by our lawmakers which necessarily or incidentally require[s] an inquiry into the race or color of its citizens. that its provisions may be enforced or which relegates to individual judgment on a question so nice and narrow as the question of the race of any citizen is contrary to good public policy, which must lead to serious blunders and which must prove odious in the extreme to all rightly and well constituted citizens; and be it

Resolved, That the object stated: "An act to promote the comfort of passengers on railway trains" can be better attained, with honor to the State and justice to all concerned, by compelling the railway companies to provide first and second class accommodations with charges accordingly, by which means, the respectable travelling public would be relieved of contact with objectionable persons of whatever race or class, and be it

Resolved, That the sentiment of these resolutions do apply to the question of separate waiting rooms, as well, and be it further

Resolved, That a copy of these resolutions be published in the newspapers of our city and a copy sent to the Arkansas Legislature with a request that they be read. Re spectfully submitted, I. E. Bush, J. H. Smith. Y. B. Simms, W. H. Scott, G. N. Perkins. ${ }^{16}$

${ }^{10}$ Gazette, Jan. 20, 1891. The Freeman, Jan. 31, 1891, reported that this meeting was organized by the Ladies Auxiliary of the YMCA, and this $\mathrm{J} C$. the resolutions. John $E$. Bush hat been land Office in Jitle Rock and was a prominent black Republican. 
DOCUMENT NO, 2:

Second Black Protest Meeting

An audience of several hundred colored people, with a small sprinkling of whites, as spectators, assembled in the Representatives' Hall last night, the purpose of the meeting being to express the disapprobation of the colored people against the Tillman Separate Coach bill, now pending in the General Assembly.

There were perhaps 400 negroes in the assembly last night, and the best of decorum was observed throughout the entire proceedings, which, upon the whole, were in teresting. ... .

The meeting was opened with a vocal quartette "Fear Thou Not," . . . The first speaker was Prof. J. A. Booker, who occupied the Speaker's stand, and entertained his audience about an hour.

Just as the speaker began his remarks the fire bells began ringing, but he said the cause which brought them together was of such vital interest that they could turn a deaf ear to the fire bells. He was a native citizen of Ar.kansas, loved the State and her institutions, and was there as a citizen to exercise a freeman's rights. ...

They had not assembled to defeat the separate coach bill, but to state their position, which had been grossly misrepresented, and to refute the misrepresentations.

It had been stated that the most offensive negroes were those who had been educated and were acquiring property. He did not believe that the white people entertained such a sentiment. If so, it was better that the negro cease to educate and that the wheels of progress be turned hackward. They did not onpore the Separate Coach bill because of a desire for social enualitv. Every prooressive negrn had long since forgotten the nhrase. and if it was no more remembered by other races than by his, the term

Smfth was a I.ittle Rnck dentist. Sims was minister of the First Congregational Church. Perkins was "a powerful figure in Little Rock's third ward who figured prominently in state Republican circles and served for a time as a city alderman." Gatewood, "Arkansas Negroes in the 18?0s: Documents," 302-303. would become obsolete in one year. What they wanted was social protection. They had nice homes and happy families as other people and were entitled to such protection. . .

It was just as true to maintain that all white people were alike as that all negroes were alike and that such measures as the proposed Separate Coach bill always failed to work harmony among the negroes. He wants social protection, especially for that part of the negro race that buys soap, goes to school and are progressive.

The educated and progressive negroes haven't time to be boisterous. They are looking forward to greater achievements for their race.

He couldn't tell how negroes were to be like white folks if they were shut off from the white folks and their example.

He did not think the railroads would furnish equal accommodations if the bill became a law. The negro patronage to the railroads would be so small that the railroads couldn't afford to furnish equal accommodations.

He thought the wholesale separation of the races without fitness meant race humiliation.

He wanted the railroad officers to be required to see that uncouth and ill-behaved people were not allowed passage on the trains. A railroad coach is not society. He wanted the laws so amended that the railroads would not be allowed to sell first-class tickets to second class people of either race. Conductors ought to be empowered to put off a passenger who boards the train on the outside of a barrel of whiskey. He intimated that such legislation as the Tillman bill contemplates would drive his race in Arkansas to Oklahoma or Africa, where they are being invited.

Dr. I. H. Smith was the next sneaker. It was humiliating to him to be a National beogar. He was not a beggar for any physical or domestic comforts. but for civil liberty.

He had lived for twenty vears in Arkansas: came here from Chicago, where he lost evervthing in the great fire. Arkansas had received him kindlv and treated him well. He had accumulated something and felt an interest in the 
State as a citizen and taxpayer, and he was indebted to the white people for patronage and encouragement. He thought he knew more about the bill than Senator Tillman did. Believed he knew more about the people of the State than Senator Tillman because he was the representative of three races, the African, the Indian and the Caucasian.

The white people have been the negro's teacher and if the negro was wrong it was because he had been taught wrong. . . His people as a race were morally inclined. He demonstrated this by reference to the Third Ward, in this city, where the negroes have a majority. The negroes voted whiskey out of that ward until the last election, when one ballot-box got into two and the ward went wet.

The negroes in Arkansas own $\$ 8,000,000$ in taxable wealth, and were entitled to consideration as taxpayers.

Turning to The Gazette reporter, he asked that in the future the expression "black heels on white necks" be kept out of its columns. He thought such sentences in the public prints were calculated to engender race prejudice. He had read The Gazette for twelve years and liked it for its news. .He didn't think such a thing as a negro uprising had any significance. If it meant anything it meant the negroes were running to get out of the way.

He thought the white men, who, at corner groceries, sold the negroes mean whiskey full of dynamite, were in a great measure responsible for the immorality of a certain class of negroes.

The negroes didn't want to ride in the cars with whites because they were ashamed of their own race, but they had educated men and women among them whose department entitled them to recognition in the way of first-class accommodations. The negroes didn't want to intermarry with the whites, because, among their own women they had all the varying hues of color from the deep-dyed Etheopian to the blue-eyed blonde, who are so near the line of being white that you can't tell where one begins and the other ends.

He was afraid the separate coach bill would drive labor from the State and that circulars are being now scattered over the State advising the negroes not to make arrangements for another year, but to await the action of the Legislature on the Tillman bill.

He had no faith in the railroads giving them such accommodations as the whites would be supplied with. He had faith in the good intentions of Senator Tillman and the supporters of the bill.

There being 2,063 miles of railroad in Arkansas, it would, according to an estimate made by himself, require upon the part of the railroads an expenditure of $\$ 63,500$. This, he said, would amount to more than the patronage of the negroes would be worth to the railroads.

Rev. Asberry Whitman was the next speaker. He was brief and to the point. He was disposed to admit that argument against the bill was a waste of words. But he thought if there ever was a people on earth who could afford to be fair it was the Anglo-Saxon race of Arkansas. "But if it comes to pass that you will have things your own way, see to it that the better element of our race is protected." $\mathrm{He}$ feared that the railroads would not give the negroes equal accommodations, because they are managed and officered by foreigners who have no interest in common with the negro of Arkansas. He paid a high tribute to Arkansas as the State where the negro is making more progress than in any other State, and that the eye of the negro is turned toward this State as the one where he can, with the greatest ease, acquire a home. ...17

\section{DOCUMENT NO. 3 :}

Senator George W. Bell Attacks the Separate Coach Law

Mr. President-If the measure under consideration has for its object the regulation of passengers upon the basis of their deportment, I am, with a few exceptions, in favor of it. But sir, after reading the bill with much care and dcliberation, it appears to be pregnant with only one aim, and that is on the lines of color, which, in the light of

\footnotetext{
${ }^{17}$ Gazeite, Jan, 28, 189!,
} 
reason, seems to me a most unfortunate affair. I am aware, Mr. President, of the fact that the press of the State, the great moulder of public sentiment, have been agitating the principles contained in this measure, to the detriment of the race with which $I$ am identified. You have pictured to your minds only one side of the question, and have drawn your conclusions and deductions from a onesided proposition. A just Judge will hear both sides of a case, and then render his decision in accordance with the facts presented. But to claim that certain citizens of our State are not comfortable, because their eyes happen to espy a man or a woman with African blood in his or her veins sitting at a distance from them within the same coach, seems to me, Mr. President, the height of inconsistency. The negroes have been riding upon and within the same coaches, in common with all other races, in this State for more than eighteen years. And during that entire period they have had no race wars, but, on the contrary, have behaved themselves quite as well, if not better, than some of the other races. . . .

It seems strange to me, that though there are five races of men known upon the face of the earth, many of which are represented in the United States, and in the State of Arkansas, as yet from among them all, the negro race has been singled out as the object of your scorn! That he should receive no better treatment than this, in his own native land, is a wonder to all lovers of justice. . . . Turn your eyes where you may, in our Sunny Southland, you behold millions of broad and fertile acres, in a high state of cultivation, the trees from which were felled and the land cleared by my ancestors, and today, thev are holding the supporting props of the South. The negro is your greatest wealth producer. He has taken an artive part in all the great battles, for the protection of our country. His blood was the first offered upon the altar of his country to appease the wrath of the British I ion. His hones lie bleached unon many a battlefield and his blond is minoled with that of the Caucasian race in the defence of his country, and is today flowing onward and upward through the fountain of liberty, crying for justice and equal rights before the law, and the protection to life, property and the general pursuits of happiness!

It is said that the founders of this government, having been oppressed in the country from which they came, sought this goodly land, upon which to build an asylum as a refuge for the oppressed and persecuted and unfortunate of every land. Actuated by the spirit of fairness and justice, the great and noble Jefferson, the father of Democracy, the author of the Declaration of Independence, an instrument sacred to the heart of every American (be he black or white, rich or poor) to write: "All men are created equal, that they are endowed by their Creator with certain inalienable rights, that among these are life, liberty, and the pursuits of happiness." To deny the negro these rights, guaranteed him by the Constitution of the United States, and the Constitution and laws of the State of Arkansas, you must first deny Jefferson's proposition, the author and finisher of your faith, that all men are created equal, and are therefore not endowed with certain inalienable rights, nor are they entitled to life, liberty and the pursuits of happiness. You will have to deny, that which is self-evident, to every reasonable mind, that we are men.

Science has demonstrated the fact that negroes are possessed with the same attributes in all respects in common with the human family of which he is a member. That he has not reached the highest stage of civilization is true. That the inhabitants of Africa, near the banks of the Nile, with negro blood coursing through every fibre of their bodies, were the first inventors, and from whom the historian tells us flows the stream of all knowledge, is also true. That when Greece and Rome lie steeped for centuries in the cesspools of illiteracy and barbarism, Africa, the home of our ancestors, could boast of a high state of civilization, is also true. That the first inventors, though their inventions be crude, are the hest inventors, is also true. That the Britains, when the Roman government was spreading its 
sway over the world, were found living in caves and wearing the skins of animals, drinking human blood as a religious test for piety, pirates and robbers upon the oceans and scas, and were so hideous in their deportment and general make-up, that Julius Caesar warned his countrymen that they were not even fit according to his judgment, for slaves, is a historical lact. But today, while Rome and her mighty sceptre are sleeping beneath the ruins of time, the Britains and their descendants are enjoying the highest civilization man ever knew! So to reason, and conclude, that because a people have once lived in the lower state of degradation, or because their skins are different from ours, that they are not entitled to the same human and christian rights that belong to other members of the human family is to destroy the very foundation stone upon which this mighty fabric rests so well planned by your ancestors, and so well built and protected by your and our fathers!

Then, Mr. President, we hold that to single us out as objects worthy of scorn and derision, because our skins are black, is an injustice as odious, and as malignant and cruel as the gravel Are we yet slaves and therefore deemed unworthy to travel on the public highways in common with freemen?

We deny the assertion so often made by some of the friends of this bill, that the negroes seek social equality with the white people, when he rides in a coach for which he holds a ticket, in common with other passengers. I am frank to say, that no true negro desires social equality with the white race, to the extent of losing his race pride, that which God seems to have fixed unalterable as a characteristic mark, into the heart and soul of all nations. We have our own churches separate and distinct from yours, our social entertainments and all our gatherings for pleasure. We have never sought to marry among you, though we have among us a peculiar people called mulattoes, the history of whom is a mystery to us, and an astonishment to the civilized and moral world.

I regret, Mr. President, that this issue has been forced upon us. Our people want peace and desire only to be let alone to fight our battle through life as the German, the Irishman, and the Italians who infest Castle Garden, seeking refuge among us from their oppressors. We hold no malice in our hearts against any one for the wrongs done us and our fathers. We seek no revenge, but rather commend those who labor under a conscientious belief that they are working for the best interest of their constituents and of the State, to God who is the Giver of light to any conscience ready to receive it. . .

I have witnessed with pride and patriotism the remark. able progress our grand old State has made since the days of reconstruction; I have sung her praises in Northern climes while others were striving to throw odium and dishonor upon her fair name and honorable citizens. I have boasted of the equal show that the negroes have in this State in the procuring an education, and the accumulation of wealth. How just and equitable her laws, and how liberal and well disposed her rulers. That in our State, race wars have never occurred. That even in the largest Republican districts throughout the State, the negroes are beginning to do their own thinking, and voting with their best friends, wherever sufficient encouragement is given them. This feeling of unrest and a desire to make peace with those whose interests are in common with ours, seems to be permeating every Northern State wherein there are negroes. If this measure becomes a law, Mr. President, I venture the assertion that the hand of our fair State's progress will be turned back to those dark and stormy days of reconstruction when scheming politicians would take advantage of the times, and engendered bitterness and violent controversies between the whites and blacks, which would excite mobs and massacres, and finally result in a war of races.

We have always granted to you, your boasted superiority, and your magnanimity in dealing with your humbler and weaker brother. You have given us schools and our children are learning and improving their conditions. They have a greater love for the State which gave them birth 
and a feeling of patriotism for their Sunny Southland that they never felt before. Then, Mr. President, we beseech this Senate in the name of those, those throbbing hearts are vibrating with the same love of country, with the same interest in his Southland to vote down these measures. My people, Mr. President, think it strange that the bill deems ignorant nurses, of our race, better than our most refined and educated men and women. But sir, I thank God that the day is fast approaching, when reason, and a proper regard for the rights and privileges of all our countrymen, North, East, West and South, will be recognized, and that the races, here in our fair and beautiful Southland, may feel and know that we have a common cause, a common humanity, and a common interestl And if we would triumph over wrong and place the emblems of peace upon triumphant justice, without distinction of race, color or previous condition, we must unite and cultivate that spirit of friendlinesss, which would make of us one people, in a truly solid South.

The bill passed, yeas 26; nays 2; Senators Hill [a white member of the Union Labor party] and Bell voting in the negative. ${ }^{18}$

\section{DOCUMENT NO. 4 :}

Two Black Representatives Denounce the Bill

... [R. C. Weddington] said the colored people always conceded to the whites their superiority over all other races. The bill was originated, not for the benefit of the interests of the two races, but on account of politics. The Democracy was fretted because the colored people voted the Republican ticket. What had the Democratic party ever done for the negro? Nothing. The more the colored man tried to get along with the whites the more the latter tried to humiliate him. The more knowledge he acquired the greater was the desire of the Democracy to oppress and degrade him. Everywhere he went he could hear "nigger, nigger, nigger," as though there was something filthy about

\footnotetext{
18Ibid., Jan. 30, 1891.
}

him-a loathsome creature in whose make God had forgotten something. The speaker did believe the State would continue its progress if the bill should become a law.

Mr. [J. A.] Donohoo said the passage of the bill was a foregone conclusion and the quicker it was passed the better. He believed that it would be to the advantage of the colored race, if such a law should be enacted. It would result in a future benefit to the colored race. He also believed that the time would come when the negro would supplant the white man in the South. If there was to be any more legislation on this subject he wanted it to come at once, and then there would be a solid black race against the white race. Pass all the bills of this character and then let it be known that there were two races in Arkansas that had nothing in common with each other-the white race and the African race. ${ }^{10}$

\section{DOCUMENT NO. 5:}

John Gray Lucas Delivers the Major Attack on the Bill . . . I deeply deplore the fact which stares me in the face with an almost blinding intensity, that either an untoward fortune or a benign Providence has placed about me and my people a barrier and an environment, which compels me to designate and to speak of a certain portion of our citizens as a class, and as my own people. You who represent the majority in this House are alone responsible for this. Whether of Puritanic stock, seeking an asylum from the heavy handed oppressor of monarchial England, or of Jamestown extraction seeking an Eldorado of ease, the water troubled into waves by the sail-filled vessel that wafted you to this smiling land had not resumed its peaceful level when in its wake followed another vessel ladened with the groans of a people despairing and heartbroken; torn from their fatherland to serve as slaves to an alien and superior race. The sufferings of the Jews in Egypt of Biblical history; of the Christians of the Spanish Inquisition; of the Irish, or of the Russian Jew of today, pale into an insig.

\footnotetext{
"Ibid., Feb. 18, 1891.
} 
nificant nonentity when compared with the sufferings that my people have endured.

The horrors of the middle passage may never be portrayed, but the whitened bones of the innocent dead as they lay in the vessel's course as they plied nefarious their trade o'er the trackless deep, "they cry from unknown graves, "we are the witnesses." "Freed by a long train of events by force of circumstances, because it was and is right that men should be free, after twenty-seven years of freedom and twenty years of citizenship in the land made rich by our toil and our tears, we have been oppressed in our liberties inch by inch until the very name of the Constitution and the Constitutional Amendments have become a byword and reproach, serving only to remind us of our utter helplessness and hopelessness.

Out of the waste of the former slaveholding states, the colored citizen of Arkansas has been wont to boast, that in his state, at least, he was as free as every other citizen under her sacred protection, and that from one cover to the other of her beneficient statutes, no law nor allusion marked a prohibition nor designated him on account of his race; and that here, at least, a man was a man for a' that. . .

When I shall next meet my friends of other portions of the country, I shall do so with uncovered head, and a becoming expression that shall be in keeping with my feelings, should this measure pass; for in view of the Separate Coach bill, I must admit to all who heard or read my proud assertions regarding my native State, that she had predestined and proscribed the class of her citizens to which I belong to moral obloquy and degradation. . . . Arkansas shakes hands across the Mississppi's [sic] murky waters to her nether shore, and aligns herself with her now notorious prototype.

My people have been charged by some of the newspapers of being ashamed of their own people, and I here take occasion to say that the assumption as stated and meant is utterly false.

We are proud of our people; proud of our wonderful progress from the degradation forced upon us to education and intelligence; proud of our noble and aspiring ambition; proud of the ability we have shown to take care of ourselves in the great and unequal contests in our country, under the shadow of an arrogant and superior people, for life, liberty and property; but most proud are we of the high moral standard to which we aspire and have in great measure attained.

In this particular we might have done less and still have been worthy of praise, for in all of our moral shortcomings, we have not only had bad models in many in stances,, but we have in most of our failings been often aided by your superior intelligence. But we are ashamed of some individuals of our race, as you should be of many individuals of yours; but it is not true that we are ashamed of any portion of our race as a class. We have no caste distinctions, based upon color, as has been intimated, for whom we desire special coaches; neither have we distinction of class as have you, but upon a broader plane; the colored people honor individual worth and integrity in whatever circumstances in life found. . . .

It cannot be denied that glaring and blatant as was, and has been the course of Democracy in the South, in the unlawful and forcible disfranchisement of a class of its citizens, yet, without denying, evading or palliating those facts charged against them, the overwhelming majority which that party returns to the next Congress, shows that, however wrong the act of suppressing votes may be, the sentiment of the country is firmly set against political, sectional and class legislation as the people understand it. The Democratic party in the South, and particularly in the State of Arkansas, if they read history with a discriminating judgment, should know that history repeats itself, that reforms do not move backward, and that if success have power to elevate it hath also strength to degrade.

The Democratic party in the pursuit of a just course might well divide, if not altogether assimilate the colored vote of Arkansas and of the South, as it has already done in 
a great measure in the North. But no party, by the abuse of its power, has ever made friends of the people they oppress. The colored man of the South, and in Arkansas, is not so much a Republican from choice, as from circumstances. The Democratic party has an opportunity to make friends with the black man. Will it do it? ...

The bill now before this House for ultimate and final action is one of those measures which, had it been introduced ten or fifteen years since, would have provoked little if any adverse criticism or opposition. But the measure, coming at this time, is without the semblance of justification or palliaton; for if for political policy, it is an unworthy method of attaining that object. We are opposed to the measure because, if not unconstitutional, which we deny, regardless of what some courts have declared the law, it is contrary to the genius of our Government as expressed and as read between the lines of our State and National Constitutions. Though Mr. [Benjamin Ryan] Tillman, of South Carolina, has denied the divine truths uttered by Jefferson, and as signed by John Hancock and others, "that all men are born free and equal and endowed with certain inalienable rights to life, liberty and the pursuit of happiness," yet, we predict that these immortal truths of Jefferson, which he stated as truths "self-evident," will survive the attack of this lilliputian. . . .

Jefferson believed in individual and universal liberty, with the slightest possible centralization of government, but believed not at all in paternalism. You Democrats who favor this measure review the catechism of your faith and see if your Democracy coincides with your great prototype. We are opposed to the measure because it prohibits and prevents frec men not only to choose their own company, but wrongfully and unlawfully restrains the citizen in his person. It is duress restraint of liberty. It is by all laws known as unlawful imprisonment; for the State has no right to make a law which distinguishes between its citizens by reason of color, and for that reason to say that you whose skin is white shall go into this place, but you whose skin is darker must enter here. The State has no right to grant certain liberties to one class and to restrain another class from the same privileges both being citizens under the Fourteenth Amendment to the Constitution. . . . We are opposed to the measure because it seeks to pander, not to the conveniences of the people, but to gratify and keep alive a prejudice among our citizens, fast becoming extinct. We are lastly and most strongly opposed to the measure, because the spirit that actuates the supporters of this bill is that same spirit that has placed itself in the path of liberty whenever and wherever she has been opposed.

We read between the lines of the Separate Coach bill the same spirit and intent which you claim in opposition to the "Force Bill."20 The provisions as seen between its readings, mean degradation, not elevation; obloquy, not civil citizenship; civil ostracism, not civil recognition; and lastly, it means inferior and insufficient accommodations for the colored man-the "jim crow car."

The wording of the bill, apparently intending to secure "equal accommodations," is a delusion and a snare. The railroads will not comply with the spirit nor the ap parent provisions of the bill. The author of this bill charges the colored people with the old "hue and cry" and bugbear of a few woeful misconstructionists, "social equality." This is the Democratic nightmare as a "whip to hoarde the wretch in order." The only trouble is this: that the gentleman cannot or will not see the distinction betwixt civil equality and social equality. Civil equality is the right to have what you pay for, and to enjoy it as any other citizen, regardless of color; social equality cannot be regulated by any law; it is a law unto itself. He [State Senator Tillman of Arkansas] says he can't see the distinction between having our own churches, schools, hotels, etc. Well, the gentleman has two distinct ideas very badly mixed. The hotel and the railroad car are public servants. They are for the accommodation of the public; for whomsoever may

${ }^{20} T$ his is a reference to the Lodge Elections Bill defeated in the United States Senate during the 51st Congress (1890-1891). 
apply in proper condition to receive their privileges. No sensible man expects social recognition at a public place, or upon public carriers, whatever his race, simply because he pays for their privileges. The hotel and the railroad car are like the highway, but upon a more limited scale. The railroad is nothing but a private highway for the accommodation of the public. It would be just as reasonable and proper for the State to place a dividing line through its public roads for the two races, or to require cities to divide their streets, or even to require all white people to live in one particular portion of our cities and the colored people in the other portion, or if you please, in different towns. It would be quite as sensible and consistent as to compel railroads to furnish "separate accommodations." There are no laws requiring white and colored people to attend separate churches, because this is a social affair and society regulates itself. The church is a large family; it is a congregation and aggregation of individuals who have agreed and do agree to work and associate themselves together for religious purposes. A stranger to the agreement has no more right to force himself upon them as a member, than he has a right to force his companionship upon a family or an individual. The privileges of the highway, of the railway, and of the hotel, as well as the public theatre, are inherent rights under our Constitutions and laws, while those of the family and the church are individual and acquired rights, depending upon the mutual consent of two or more persons: In other words one is a natural right of which the State has naught to do. The State cannot select my friends nor associates.

Those who charge us with desiring social equality and of forcing ourselves upon our white neighbors should re. member that whatever mingling of the races that has occurred, was not sought by us; neither were we the invaders, but in nearly every instance we have heen the victims and we the invaded. Out of a bounty and plenty of culture and refinement we are satisfied and glad to wed amongst our own; for have we not samples of all complexions and fea- tures and texture of hair, if you please, that all the races afford, from the fair-haired daughter of the Caucasus to the raven-haired maid of voluptuous Spain. He or she among us must indeed be an epicure that from our goodly quantity and from among our differing qualities may not find satisfaction. It is the dissatisfaction of some of our neighbors with their own, it would seem that for their own restraint (which does not restrain) they must have laws to prevent this race antipathy of which they love to prate. Is it true, as charged, that we use less of soap and God's pure water than other people, that it is sought to isolate us from other fellow citizens? It has been heralded to the world by those who would justify the Democratic party of Arkansas in their platform of 1890 demanding "separate coaches," that the negro is not so clean and pleasant to the eye as he should be; but that some few other negroes are less objectionable because refined, intelligent and genteel. Why, some of our Democratic papers have said that the more money, intelligence and gentility, the more objectionable the negro. Which is the truth? Do our white friends demand this law that they may not be compelled to travel in the same car with the former class? $O r$ is it the constant growth of a more refined, intelligent, and I might say a perfumed class, that grow more and more obnoxious as they more nearly approximate to our white friends' habits and plane of life?

Who are employed as your servants throughout the South in preference and to the exclusion of every other class? Who is he that attends to the very delicate duties that bring persons in closer relations than any other; that sits by the side of yon delicate and refined white lady, laughing, chatting, covered by the same lap cloth? Who is the scraper of your chin with his face and breath close as the "lover sighing like ballad?" Why, I have heard many say that none but a negro should shave them. How about those cooks who handle all that passes over your delicate palates and the baker who is said to knead the dough with feet as with hands? How about those nurses that must sleep 
with the children, go traveling with you, occupy the room with you and the bed with your loved ones? Do you stand all this (and I have not half portrayed it), and yet you can't bear to ride upon the same car, though in a separate seat from your colored fellow citizen? It seems and must appear to every reasonable man to present a peculiar consistency; but "Consistency, thou are a jewel." The advocates of this measure would not hesitate to assert that a drunken white man is preferable, as a fellow passenger, to the most genteel negro. To those whose objections coincide with [U. S. Senator from Louisiana James] Eustis and others of his type, that the negro is naturally inferior, and by consequence not entitled to civil liberties in common with other citizens, we refer with pride to history, which shows the black races of Africa to have been the very first to invent farming implements, even before the establishment of tradition.

We refer you to that most ancient civilization of Egypt, whose people were mulattoes, originating by amalgamation between the black and white races. This, their features as carved upon Egypt's monuments, and the hair and features of her exhumed mummies, attest. And Egypt, that built the pyramids, learned her mathematics from Ethiopia. . . .

These facts we learn from Herodotus, Diodorus, and other ancient writers. They were the founders of some of the greatest cities, the ruins of which lie scattered along the Upper Nile. These compare in grandeur and antiquity with any in Egypt herself.

It is true that, though flourishing as were these cities of the blacks with their wealth and sciences, they rose, reigned and fell, relapsing into barbarism and ignorance; but this is also true concerning countries inhabited by the Caucasian race. Europe had relapsed and returned to the most debasing ionorance after the invasion by the barbarians in the Middle Ases. There was an African traveler of great talent, named Ion Hatukel IIbn Haukall, who lived in the Tenth Centurv and traveled amono the now Europeans, as has Stanley among the Africans. He said of them even at that late date, "as to the Nazarenes (the Christian nation) I will pass over briefly; for my inborn love for wisdom, justice and good government prevents me from mentioning and praising anything among these nations." And this was one thousand years after Caesar saw them living in mud huts and war paint, like an Apache Indian of today.

The colored people have been contented here to bear some of the ills that are necessary and incident to the poor in all places, rather than flee to others they know not of. They have been wont to feel proud of this, their State, until now; but this last ad outrageous measure may prove the straw to break the camel's back.

The tocsin of evacuation has already been sounded among the more easily disturbed. ${ }^{21}$ There are those of the West who will welcome and assist the colored laborer of Arkansas to shake the dust from his feet. They are already leaving in considerable numbers, from the country farms, as from the cities, right under the shadow of our State House. Others are preparing to leave and will be ready to go before this law shall go into effect. You may answer, let them go, and it will relieve us of some troublesome majorities; you will not take warning in your oppressing course until, like the Mississippi exodus, your fields have become deserted, your cabins left tenantless, and where the cotton and the corn were wont to grow in plenty and abundance, you find the jimson and the cuckleburr growing in rank profusion over the once fertile fields, and about the cabin doors. ...

When north of Mason and Dixon's line, well pleased was I to have my native State considered a Southwestern State. It is true in fact, that Arkansas is geographically a Southwestern State, but from the trend of present and proposed legislation, Arkansas seems determined to trans. port herself bodily into the South and across the Mississippi River, where yoked to the crimsoned soil of Mississippi,

${ }^{21}$ See Edwin F. Redkey, Black Exodus (New Haven, 1969), 107-117 for a disfunssion of black emigration from Arkansas in this period. 
she shall be as incapable of advancement as is a fixed star to alter its course, She will then be as finished a State as Mississippi now is. All the Southern States have not had a "Separate Coach bill." Why, even South Carolina, with her new fledged Gov. Tillman, the refuter of the time honored doctrines of Thomas Jefferson, with the largest negro majority in the United States, with more reason on that account for complaint against the eyesore of the South, her colored citizens, only a few weeks since refused to pass the odious measure known as the "Separate Coach bill." This, if nothing else, and in spite of the Tillman doctrine, denying the equality of men, will crowd the colored citizen of South Carolina around the Alliance standard, and in a great measure, bridge the gulf which has seemed widening for a quarter century.

I believe the title of this bill as it stands, is "An Act to promote the comfort of passengers on railway trains. . . ." [On the contrary, it] is a bill to further alienate the white and black people; call it, if you please, a bill to promote the comfort and to pander to a dying prejudice of certain white passengers, regardless of the rights of colored passengers.

Designate it as the very head and front of all the offenses heaped upon a despised race, because so long and often wronged. It is said that the oppressor always hates the oppressed.

We ask no special favors, nor do we desire class legislation for our benefit or protection. . . .22

\footnotetext{
:2Gazette, Feb. 21, 1891.
}

\section{News, Notes and Comments}

The Garland County Historical Society Record took the Award of Distinction at the first annual presentation of awards by the Arkansas Historical Association to county publications. These presentations were made at the Association Banquet held April 25, 1975, at the annual meeting in Jonesboro. The Independence Counly Chronicle, published by that county's historical society, received the Award of Excellence and the Grand Prairie Historical Society Bulletin was presented the Award of Merit. Jno. P. Morrow of Batesville received the Award of Distinction for the single best article appearing in a county historical publication for 1974. His winning article was "Batesville's Involvement in the War With Spain, 1898-1899," published in the Independence County Chronicle. Malcom Moore, first vice president of the Association and chairman of the Awards Committee, made the presentation.

Robert L. George of Cleveland, Tennessee, has become a Life Member of the Association. Dr. Waddy W. Moore, president of the Association, has contributed toward the Permanent Membership for Hugh Park.

The Crittenden County Historical Society was organized October 15, 1974, at West Memphis. At the present time the society has approximately 100 members. The dues are $\$ 5.00$ per person, $\$ 10.00$ for a family, and $\$ 3.50$ for a student. The society plans to establish a museum and the Bicentennial Commission has granted $\$ 3,000$ for that project for which matching funds are available. The society is also making aprons that turn into sunbonnets for additional revenue toward their project. Mrs. Thomas I. Sims, 401 Gibson, West Memphis, Arkansas 72301, president of the society, can be contacted for more information. 